\title{
Rejoinder to Lansing and de Vet
}

\author{
Andrew P. Vayda
}

Published online: 31 May 2012

(C) Springer Science+Business Media, LLC 2012

Since synchronous fallowing is the practice most discussed by Lansing and de Vet in their response to my critique of Lansing's work, it's the practice on which I will particularly focus in this necessarily brief rejoinder. Lansing and de Vet correctly state that I, like others, question how well Lansing's analysis applies to conditions that existed before the Green Revolution that occurred after the 1960s. However, they then state, quite incorrectly, that I question whether rice-field pests were a problem at all before the Green Revolution. In line with this misattribution, they then devote a long paragraph to evidence of pests, especially rats, in earlier times. Actually I myself cite some such evidence as well (Vayda 2009: 41, n.50). This is consistent with my stating not that the Green Revolution rice-intensification programs initiated rice-field pest problems but rather that they exacerbated them. Lansing and de Vet do not dispute that there was exacerbation. We agree also that a probable cause of it in many cases was the abandonment of synchronous fallowing as cropping with the new high-yielding rice varieties became more frequent, although, in my mind, this was not the only or necessarily the most important cause of exacerbation in all those cases (see, for example, the references cited in Vayda 2009: 41 on other factors in regard to brown planthopper outbreaks).

About what then do we disagree? Most significantly, about the claims of antiquity that are made by Lansing and his associates for the evolution of the role of networks of water temples not only in the allocation of irrigation water but also in the control of rice-field pests over entire watersheds. Such historical claims call for more than using

\footnotetext{
A. P. Vayda $(\bowtie)$

Department of Human Ecology, Rutgers University,

New Brunswick, NJ, USA

e-mail: apvayda@gmail.com
}

present-day observations for a computer simulation of what might have happened in the distant past. They call for more and better historical evidence - evidence of what actually did happen - than Lansing et al. have so far provided. That a main object of my critique of Lansing's work was indeed this failure of evidence would, I thought, have been made clear by the fact that the critique was embedded in an extensive discussion of the problem of confirmation bias (Vayda 2009: 29-43). However, in light of Lansing and de Vet's not addressing that problem at all, I concede now that I was not being clear enough. Let me therefore repeat here something said -fairly emphatically, I thought - at the very beginning of my discussion of the problem in my 2009 book, namely, that perhaps the most common failure related to evidence in studies concerned with accounting for human actions and/or environmental changes is the failure to judge the evidence for one's favored explanation in relation to the support that either the same or other evidence provides for alternative explanations (Vayda 2009: 29; cf. Vayda 2009: 45 and, for discussions of the treatment of confirmation bias in my 2009 book, Walters et al. 2011). ${ }^{1}$

Lansing and de Vet do cite some evidence for the antiquity of water management by temple-associated subaks. However, the questions I am raising are only about evidence for the antiquity of the role of such subaks in the control of rice-field pests. The fact that some Balinese farmers suffering crop losses after the Green Revolution advocated, according to Lansing and de Vet, a return to former practices is not clear evidence that any of the practices actually developed in earlier times for the purpose of pest control.

\footnotetext{
${ }^{1}$ For general discussion and some further illustrations of confirmation bias, see the Introduction and chaps. 14, 15, and 16 of Vayda and Walters 2011, a volume in which my 2009 critique of Lansing's work is reprinted as chap. 22.
} 
Also not clear evidence of this is what Lansing and de Vet cite on the efficacy of synchronized fallowing for controlling pests. ${ }^{2}$ If the temple-associated synchronization of irrigation schedules did indeed help to keep down pest populations prior to the Green Revolution, this would not necessarily mean that farmers were "knowingly" attempting to control pests by means of their temple-associated cropping system (cf. Lansing et al. 1998: 382 on the system as the outcome of a selective process driven only by pestcontrol and water-management needs). Pest control could have been a by-product of the development of the system for other reasons.

There is, however, another possibility worth mentioning, namely, that synchronized fallowing in the past may not have required as much synchronization of planting as seems to be assumed by Lansing and de Vet. Here's why not: There appears to be some evidence that the traditional, pre-Green Revolution rice varieties of Southeast Asia, unlike the Green Revolution high-yielding varieties, "are photosensitive and mature at a particular time of the year, even when crops are planted over a period of weeks" (Leung et al. 1999: 311, citing Grist 1975). ${ }^{3}$ This is something that came to my attention only during the few days I had for preparing the present rejoinder, and I acknowledge that more research on the subject than I am now aware of is needed (cf. Vergara and Chang 1985: 20 and passim). Still, the possible causal significance of such factors as the photosensitivity of traditional rice varieties underscores that Lansing et al. have not cast a wide enough net in seeking causes of why the size of pest populations was kept relatively low before the Green Revolution and increased dramatically after it.

As a final note, a puzzle worth considering is Lansing and de Vet's criticizing me for stating, according to them, without any evidence that an alternative to rice-pest control as a cause of fallowing may be Balinese farmers' use of their land for growing commercially valuable crops like chili peppers, garlic, and shallots after rice harvests. The puzzle here is that Lansing and de Vet themselves cite me as citing Helmreich citing Nakatani (1999: 206-207), who provides precisely such evidence. Is this another indication that I am simply not on the same page as Lansing and de Vet as far as making judgments about evidence is concerned?

\section{References}

Grist, D. H. (1975). Rice, 5th ed. Longman, New York.

Lansing, J. S., Kremer, J. N., and Smuts, B. B. (1998). Systemdependent selection, ecological feedback, and the emergence of functional structure in ecosystems. Journal of Theoretical Biology 192: 377-391.

Leung, L. K. P., Singleton, G. R., Sudarmaji, and Rahmini (1999). Ecologically-based population management of the rice-field rat in Indonesia. In Singleton, G., Hinds, L., Leirs, H., and Zhang, Z. (eds.), Ecologically-Based Management of Rodent Pests. Australian Centre for International Agricultural Research, Canberra, pp. 305-318.

Nakatani, A. (1999). "Eating threads": Brocades as cash crop for weaving mothers and daughters in Bali. In Rubinstein, R., and Connor, L. H. (eds.), Staying Local in the Global Village: Bali in the Twentieth Century. University of Hawaii Press, Honolulu, pp. 203-229.

Singleton, G. R., Belmain, S. R., Brown, P. R., and Hardy, B. (eds.) (2010). Rodent Outbreaks: Ecology and Impacts. International Rice Research Institute, Los Baños, Philippines.

Vayda, A. P. (2009). Explaining Human Actions and Environmental Changes. AltaMira Press, Lanham, MD.

Vayda, A. P., and Walters, B. B. (eds.) (2011). Causal Explanation for Social Scientists: A Reader. AltaMira Press, Lanham, MD.

Vergara, B. S., and Chang, T. T. (1985). The Flowering Response of the Rice Plant to Photoperiod: A Review of the Literature, 4th ed. International Rice Research Institute, Los Baños, Philippines.

Walters, B. B., Doolittle, W. E., Klooster, D., Rocheleau, D., Turner, B. L., and Vayda, A. P. (2011). Book review forum: Explaining Human Actions and Environmental Changes [five reviews of Vayda 2009 and author's response]. Dialogues in Human Geography 1(3): 370-389.

\footnotetext{
${ }^{2}$ See Singleton et al. 2010 for much more evidence than Lansing and de Vet's on this efficacy with respect to rats.

${ }^{3}$ Leung et al. (1999: 311) note that there may have been selection for synchronous maturation as a defense against rodents or other pests.
} 